\title{
43. OXYGEN ISOTOPE GEOCHEMISTRY OF DSDP LEG 37 ROCKS
}

\author{
Karlis Muehlenbachs, Department of Geology, University of Alberta, Edmonton, Canada
}

\begin{abstract}
The isotopic compositions of minerals from DSDP Leg 37 samples indicate that the primary, unaltered $\delta \mathrm{O}^{18}$ of both the plutonic and extrusive rocks are identical $\left(\sim 5.7^{\circ} \% 0\right)$ to those of unaltered basalts dredged from mid-ocean ridges. All of the analyzed basalts $\left(6^{\circ} / 00\right.$ to $\left.9^{\circ} / 00\right)$ have been enriched in $\mathrm{O}^{18}$ due to weathering by seawater, whereas the plutonics $(2.4 \%$ and $5.0 \%$ are depleted of $\mathrm{O}^{18}$, probably as a result of exchange with hot seawater. If Leg 37 has sampled average oceanic crust, then the interaction between the oceans and the crust must be considered in discussions of the chemistry of seawater.
\end{abstract}

\section{INTRODUCTION}

Studies of samples recovered from the oceanic crust often show that submarine igneous rocks have reacted chemically with seawater both at low (Hart, 1970; Muehlenbachs and Clayton, 1972b) and high temperatures (Muehlenbachs and Clayton, 1972a; Wenner and Taylor, 1971). Implicit in current tectonic models is the hypothesis that sufficiently large volumes of oceanic crust are produced each year so that any appreciable chemical reaction between the crust and the oceans will influence the chemical composition of seawater. The magnitude of the crust-ocean interaction depends on the depth to which seawater penetrates in the crust and the temperature and average degree of rock alteration. It is important to determine the temperature of the interaction because the distribution factors of components between rock and seawater depend on temperature. Oxygen isotope studies of suitable DSDP materials can provide measures of the above three parameters.

Isotopic fractionations between minerals and water are functions of temperature, the fractionations becoming smaller at higher temperatures. Low temperature $\left(4^{\circ} \mathrm{C}\right)$ seawater-rock interaction results in the enrichment of $\mathrm{O}^{18}$ in the weathered rock, but rocks may be depleted of $\mathrm{O}^{18}$ if altered at higher temperatures $\left(200^{\circ}\right.$. $300^{\circ} \mathrm{C}$ ) (Muehlenbachs and Clayton, 1972a, b).

\section{METHODS}

Minerals were separated by density and magnetic means. Oxygen was extracted from the rock and mineral powders by the $\mathrm{BrF}_{5}$ method (Clayton and Mayeda, 1963), reacted with carbon to form $\mathrm{CO}_{2}$, and analyzed on a 6 -in. isotope ratio mass spectrometer. The isotopic composition of a sample, $x$, is given as

$$
\delta_{x}=\left[\frac{\left(\mathrm{O}^{18} / \mathrm{O}^{16}\right) x}{\left(\mathrm{O}^{18} / \mathrm{O}^{16}\right) \text { standard }}-1\right] \times 1000
$$

The analyses are reported relative to the Standard Mean Ocean Water (Craig, 1961). The calcite was analyzed by the $\mathrm{H}_{3} \mathrm{PO}_{4}$ method (McCrea, 1950).

\section{DATA}

Oxygen isotope analyses of 13 basalts from Holes $332 \mathrm{~A}, 332 \mathrm{~B}$ and Sites 334 and 335 of DSDP Leg 37 are presented in Table 1, which also lists the analyses of two plutonic rocks from Site 334 . The basalts range in $\delta \mathrm{O}^{18}$ from $6^{0} \%$ oo to $9.0^{\circ} \%$, but the $\delta \mathrm{O}^{18}$ values of two plagioclase separates from Holes $332 \mathrm{~A}$ and $332 \mathrm{~B}$, are only $5.7 \%$ and $5.9 \%$, respectively. The whole rock $\delta \mathrm{O}^{18}$ values of the plutonic rocks are $2.4^{\circ} / 00$ and $5.0^{\circ} \%$. The isotopic composition of pyroxene from one of the plutonic rocks is $5.7 \%$, but that of coexisting plagioclase is only $5.1^{1} \%$. A very $\mathrm{O}^{18}$-rich calcite disseminated in a basalt from Site 335 was also analyzed (Table 1).

\section{DISCUSSION}

\section{Basalts}

Extensive sampling has shown that all unaltered basalts and their phenocrysts recovered from midocean ridges have $\delta \mathrm{O}^{18}$ values near $5.7 \%$ (Muehlenbachs and Clayton, 1972b; Pineau et al., 1973; Muehlenbachs, 1976). Weathered basalts from the sea floor are enriched in' $\mathrm{O}^{18}$ and range in $\delta \mathrm{O}^{18}$ from $6^{\circ} \%$ to $17^{\circ} \%$. Their $\mathrm{O}^{18}$ content is directly proportional to the amount of weathering (Muehlenbachs and Clayton, $1972 \mathrm{~b})$. The $\mathrm{O}^{18}$ enrichment results from the formation of hydrous alteration products-clay or palagonite-at the ambient temperature of the sea floor, which are enriched in $\mathrm{O}^{18}$ by about $27^{\circ} \% 0$ with respect to seawater (Savin and Epstein, 1970). Phenocrysts isolated from weathered basalts retain their primary isotopic composition (Muehlenbachs and Clayton, 1972b). The analyses of the two plagioclases $\left(\delta \mathrm{O}^{18} \sim 5.8 \%\right.$ from Holes $332 \mathrm{~A}$ and $332 \mathrm{~B}$ imply that the primary isotopic compositions of all the basalts from Leg 37 fall in the same narrow range as found elsewhere, but have been subsequently altered by low temperature weathering. 
TABLE 1

Oxygen Isotope Composition of DSDP Leg 37 Rocks and Minerals

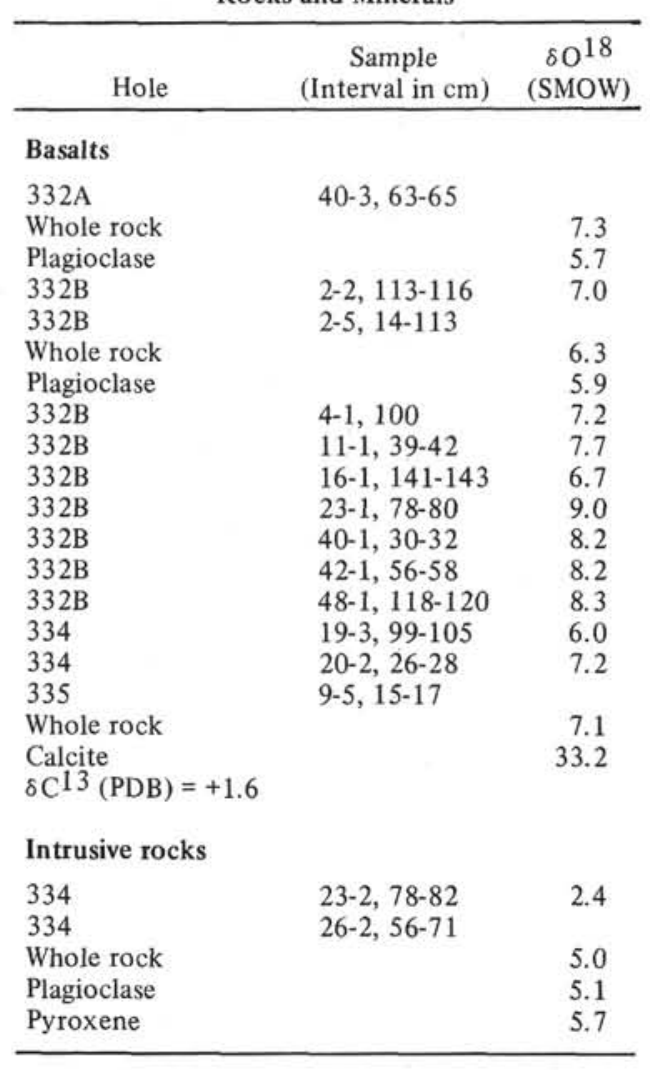

It can be calculated from their $\mathrm{O}^{18}$ content that the basalts of Leg 37 are $1 \%$ to $15 \%$ weathered. The inference of low temperature weathering of basalt within the oceanic crust is substantiated by the analysis of the $\mathrm{O}^{18}$-rich calcite disseminated in basalt (335-9-5, 15-17 $\mathrm{cm})$ which yields a paleotemperature of only $2^{\circ} \mathrm{C}$ (O'Neil et al., 1969). Identical carbonates have been found in weathered basalts dredged from the surface of the sea floor (Muehlenbachs and Clayton, 1972b).

\section{Plutonic Rocks}

The isotopic compositions of the plutonic rocks from Site $334\left(\delta \mathrm{O}^{18}=2.4^{0} / 00\right.$ and $\left.5.0^{\circ} \% 0\right)$ are comparable to those of metamorphosed basalts and gabbros dredged from the oceanic crust, the submarine greenstones (Muehlenbachs and Clayton, 1972a). These are depleted of $\mathrm{O}^{18}$ in marked contrast to the $\mathrm{O}^{18}$-enriched nature of the weathered basalts. Muehlenbachs and Clayton (1972a) found that the oxygen of the dredged greenstones has exchanged with large volumes of seawater at $250^{\circ}$ to $300^{\circ} \mathrm{C}$. The relic pyroxenes in the greenstones are resistant to isotopic exchange and retain their primary isotopic compositions. The isotopic composition of the pyroxene separate from Sample $334-26-2,56-71 \mathrm{~cm}$ is $5.7^{\circ} \%$, strongly suggesting that the primary isotopic composition of the plutonic rocks is the same as that of the unaltered basalts. Plagioclase separated from Sample 334-26-2, 56-71 cm, $\delta \mathrm{O}^{18}=$ $5.1^{\circ} \%$, is $0.6^{\circ} \%$ lower in $\delta \mathrm{O}^{18}$ than its coexisting pyroxene, and it is clearly out of isotopic equilibrium (Anderson et al., 1971). The plagioclase must have exchanged oxygen with a large volume of a hot, low- $\mathrm{O}^{18}$ fluid (Muehlenbachs and Clayton, 1972a; Taylor and Forester, 1971). Seawater $\left(\delta O^{18} \sim 0\right)$ is the only low-O ${ }^{18}$ reservoir which can be expected in the oceanic crust.

\section{Oxygen Exchange Between Seawater and Crust}

Isotope exchange processes are evident in samples from Leg 37 that lead to both enrichment and depletion of $\mathrm{O}^{18}$ in seawater. The net magnitude of $\mathrm{O}^{18}$ transfer between ocean and crust must be evaluated. It has already been proposed that the $\mathrm{O}^{18}$ gained by seawater during the formation of $\mathrm{O}^{18}$-depleted rock (i.e., greenstones) in the oceanic crust may balance the loss of $\mathrm{O}^{18}$ from the hydrosphere to $\mathrm{O}^{18}$-rich weathered crustal rocks and sediments (Muehlenbachs, 1971).

Weathering of basalt depletes seawater of $\mathrm{O}^{18}$. The amount of $\mathrm{O}^{18}$ removed from the oceans each year by this process depends on the rate of ocean crust production, the depth to which seawater penetrates, and the extent to which seawater reacts with the basalt. All of the Leg 34 (Muehlenbachs, 1976) and Leg 37 basalts are measurably weathered, even the basalts which were recovered almost 600 meters below the sediment basalt interface. If Hole 332B has sampled typical oceanic crust, then weathering of the crust is indeed a major sink for $\mathrm{O}^{18}$.

Above $250^{\circ} \mathrm{C}$, seawater can become enriched in $\mathrm{O}^{18}$ by exchange with rocks in the oceanic crust. The $\mathrm{O}^{18}$ enrichment in the oceans will depend on the amount of rock and water involved, the modal composition of the altered rock, and the temperature of the alteration. Samples from Site 334 only show that $\mathrm{O}^{18}$-depleted rocks do exist in the oceanic crust and that, as was found with dredged material (Muehlenbachs and Clayton, '1972a), coarse-grained plutonic rocks from the oceans have exchanged oxygen with seawater.

\section{CONCLUSIONS}

The primary $\delta \mathrm{O}^{18}$ value of both the extrusive and plutonic rocks from Leg 37 was about $5.7^{\circ} \%$, a value typical of other unaltered submarine rocks. The $\mathrm{O}^{18}$ content $\left(6^{0} \%\right.$ to $\left.9^{\circ} \% 0\right)$ of all the analyzed basalts has been raised by weathering. As was shown in Leg 34 (Muehlenbachs, 1976), cold seawater must have access to basalt quite deep in the oceanic crust. The plutonic rocks $\left(2.4^{\circ} \% 0\right.$ and $\left.5.0^{\circ} \% 0\right)$, on the other hand, are depleted of $\mathrm{O}^{18}$. As was inferred from the analyses of dredged material (Muehlenbachs and Clayton, 1972a), large volumes of seawater must come in contact with solidified but still hot intrusives in the crust. The processes affecting the oxygen isotopic composition of submarine rocks are readily identifiable, but the volumes of rock altered are still not known. The net transfer of $\mathrm{O}^{18}$ between crust and ocean cannot yet be calculated.

\section{ACKNOWLEDGMENTS}

I wish to thank Dr. T.C. Hoering of the Carnegie Institution of Washington for the use of his mass spectrometer.

\section{REFERENCES}

Anderson, A.T., Clayton, R.N., and Mayeda, T.K., 1971. Oxygen isotope geothermometry of mafic igneous rocks: J. Geol., v. 79, p. 715-729. 
Clayton, R.N. and Mayeda, T.K., 1963. The use of bromine pentafluoride in the extraction of oxygen from oxides and silicates for isotopic analysis: Geochim. Cosmochim. Acta, v. 27, p. $43-52$.

Craig, H., 1961. Standard for reporting concentrations of deuterium and oxygen-18 in natural waters: Science, v. 133, p. $1833-1834$.

Hart, R., 1970. Chemical exchange between sea water and deep ocean basalts: Earth Planet. Sci. Lett., v. 9, p. 269279.

McCrea, J.M., 1950. On the isotopic chemistry of carbonates and a paleotemperature scale: J. Chem. Phys., v. 18, p. 849-857.

Muehlenbachs, K., 1971. Oxygen isotopic studies of rocks from mid-ocean ridges: Unpublished Ph.D. thesis, University of Chicago.

1976. Oxygen isotope geochemistry of DSDP Leg 34 basalts. In Hart, S.R., Yeats, R.S., et al., Initial Reports of the Deep Sea Drilling Project, Volume 34: Washington (U.S. Government Printing Office), p. $377-340$

Muehlenbachs, K. and Clayton, R.N., 1972a. Oxygen isotope geochemistry of submarine greenstones: Canadian J. Earth Sci., v. 9, p. 471-478. 1972b. Oxygen isotope studies of fresh and weathered submarine basalts: Canadian J. Earth Sci., v. 9, p. $172-184$.

O'Neil, J.R., Clayton, R.N., and Mayeda, T.K., 1969. Oxygen isotope fractionation in divalent metal carbonates. J. Chem. Phys., v. 51, p. 5547-5558.

Pineau, F., Javoy, M., Craig, H., and Hawkins, J.W., 1973. $\mathrm{O}^{18} / \mathrm{O}^{16}$ and $\mathrm{C}^{13} / \mathrm{C}^{12}$ ratios in volcanic and plutonic rocks from oceanic environment (abstract): Fortschr. Miner., v. 50 , p. $119-120$.

Savin, S.M. and Epstein, S., 1970. The oxygen and hydrogen isotope geochemistry of ocean sediments and shales: Geochim. Cosmochim. Acta, v. 34, p. 43-63.

Taylor, H.P., Jr., and Forester, R.W., 1971. Low-O'18 igneous rocks from the intrusive complexes of Skye, Mull, and Ardnamurchan, Western Scotland: J. Petrol., v. 12, p. 465-497.

Wenner, D.B. and Taylor, H.P., Jr., 1971. Temperature of serpentinization of ultramafic rocks based on $\mathrm{O}^{18} / \mathrm{O}^{16}$ fractionation between coexisting serpentine and magnetite: Contrib. Mineral. Petrol., v. 32, p. 165-185. 